University of Nebraska - Lincoln

DigitalCommons@University of Nebraska - Lincoln

Faculty Publications: Department of Teaching, Department of Teaching, Learning and Teacher Learning and Teacher Education

Education

April 2002

\title{
From Neologisms to Social Practice: An Analysis of the Wanding of America
}

Loukia K. Sarroub

University of Nebraska-Lincoln, Isarroub@unl.edu

Follow this and additional works at: https://digitalcommons.unl.edu/teachlearnfacpub

Part of the Teacher Education and Professional Development Commons

Sarroub, Loukia K., "From Neologisms to Social Practice: An Analysis of the Wanding of America" (2002). Faculty Publications: Department of Teaching, Learning and Teacher Education. 32.

https://digitalcommons.unl.edu/teachlearnfacpub/32

This Article is brought to you for free and open access by the Department of Teaching, Learning and Teacher Education at DigitalCommons@University of Nebraska - Lincoln. It has been accepted for inclusion in Faculty Publications: Department of Teaching, Learning and Teacher Education by an authorized administrator of DigitalCommons@University of Nebraska - Lincoln. 


\title{
From Neologisms to Social Practice: An Analysis of the Wanding of America
}

\author{
Loukia K. Sarroub
}

Anthropology \& Education Quarterly 33:3 (Spring 2002), pp. 297-307.

\begin{abstract}
In this article I discuss how individuals and communities in the United States re-present themselves in the context of the September 11 tragedy and its complex aftermath. My aim is to explore the "American" discourse on inclusion and discrimination by examining the neologisms and social practices that were amplified by the attack in local and national debates.
\end{abstract}

Published as "From Neologisms to Social Practice: An Analysis of the Wanding of America" in Anthropology \& Education Quarterly 33, no. 3 (Spring 2002), pp. 297-307.

Copyright $(\mathcal{C} 2002$ by American Anthropological Association.

Copying and permissions notice: Authorization to copy this content beyond fair use (as specified in Sections 107 and 108 of the U. S. Copyright Law) for internal or personal use, or the internal or personal use of specific clients, is granted by American Anthropological Association for libraries and other users, provided that they are registered with and pay the specified fee via Rightslink ${ }^{\circledR}$ on AnthroSource (http://www.anthrosource.net) or directly with the Copyright Clearance Center, http://www.copyright.com.

[A text-based version follows the page images at the end of this PDF file.] 


\title{
From Neologisms to Social Practice: An Analysis of the Wanding of America
}

\author{
Loukia K. Sarroub \\ University of Nebraska-Lincoln
}

In this article I discuss how indiniduals and communities in the United States re-present thenseles in the context of the September 11 tragedy and its complex aftermath. My aim is to explore the "American" discourse on inclusion and discrimination by examining the neologisms and social practices that were amplified by the attack in local and national debates.

\section{Crafting Post-September 11 Selves}

As an immigrant of North African (Algerian) and European (Greek) descent, and as an American living in the Midwest, I, like many others, participated in public and media discourses focused on ethnicity and religion in the aftermath of the September 11 attacks. Throughout the fall of 2001, I noticed as a participant in these debates that among people who use hyphenated labels, I was perceived and categorized as either EuroAmerican or Arab American, and among some, I was regarded as a hybrid (an American), while among others who questioned my "unusual" name, the inevitable question arose, "So, what are you?" I wondered if there is a way to respond to the dilemma that the "What are you?" question poses in times of crisis and catastrophe. In the wake of the attack, I became more interested in understanding how our communities adapt to the often subtle and sometimes explicit demands on our emotions, time, and intellect in the private and public spaces of our lives such as schools, communities, and homes. How do individuals and communities $r t$-present themselves in the context of such an attack and its complex and complicated aftermath?

It has long been considered a truism that how we perceive, represent, and act around others defines our individual and collective identities. The September 11 tragedy and the ensuing political and military events rendered people in the United States and elsewhere more sensitive to the particularities of perception and representation. In my own scholarship, I have suggested that immigrant communities live in the "in-between" spaces created in the nexus of ethnicity, nationality, and culture, and that people's textual and social practices reflect and refract their in-betweenness (Sarroub 2002b). However, during times of crisis, people inevitably have to choose how to represent themselves in order to survive,

Anthropologry \& Eduation Quarterly 33(3):297-307. Copyright (1) 2002, American Anthropological Asscriation. 
and being "in-between" may not satisfy common local and national expectations of what it means to be a member of a given community.

My own "Algerianness" was foregrounded both on personal and professional levels after September 11. For example, like most people around the world, I watched and read the news avidly; I cringed every time I noted that yet another individual from the Middle East was part of the attack, and I was ever watchful of Algerians' possible participation in this act of terror. I watched and I, too, wondered if I was watched under the panoptican-like gaze. The "What are you?" question became a haunting metaphor for the fear and apprehension I witnessed in various immigrant communities, and my work on Arab Muslim youth in the United States became more significant as I attempted to answer hundreds of questions from educators, researchers, and my neighbors (Sarroub 2001, 2002a). People wanted to know more, for example, about where these Arab and Arab American communities are located, who the youth are in our schools, and how they might be related to the events of September 11 .

This process of answering questions and looking at research through the tragic lens of September 11 indexed something new in my work and that of colleagues who study a range of communities in the United States. Catastrophic events and their consequences had to be interrogated through a critical lens no matter where they occurred. Research sites were no longer just schools or communities that could be discretely described, analyzed, and then discussed in the research community. The geopolitical ramifications of the attack underscored the notion that everyone is an active participant, a participant observer, and deeply:implicated in the consequences of such a catastrophe, especially in this digital age when images and text are so quickly and easily accessible. In effect, we all became observers of our participation as individuals across the United States and elsewhere grew more watchful, or as the case may be, more watched.

Since September 11, people in the United States and much of the world have been engaged in three broad discourses regarding war, security versus civil liberties, and inclusion and discrimination. For example, we have all wondered if we are at war and if fighting terrorist networks means that we are fighting a new kind of war. Most of us have experienced the new security measures at airports and debated the advantages and disadvantages of national identification cards. Finally, in the United States, discrimination and "racial profiling" at all social and professional levels have long and complicated histories and continue to be problematic societal issues.

My aim here is to further explore the third discourse on inclusion and discrimination in the context of my research in Arab American communities. At the heart of this discussion are the questions: "Who is American?" and, "What does it mean to be an American?" Both closely relate to the "What are you?" question. Since September 11, we have observed, 
watched, and participated in a public accounting of this question. For example, in the September 23, 2001, Now York Times article, "Identify Yourself: Who's American?" Gregory Rodriguez makes the following observations about U.S. society:

1. Not until the 1960 s was it permissible for immigrants to adhere to their cultural heritages. The definition of citizenship shifted from belief in a common culture to following shared ideals.

2. Since the $1970 \mathrm{~s}$, multiculturalism nurtured unprecedented levels of public tolerance of ethnic and racial differences and respect for hyphenated identities.

3. Some people even espoused a form of multiculturalism that challenged the need for immigrants and other minorities to identify with America at all.

4. By the end of the 20th century, being American simply meant being a participant in the search for wealth and stability. [Rodriguez 2001: D1]

The attack of September 11 changed what seems to have been a rather flexible ideology of Americanness. The attack provoked renewed vigor and an explicit accounting of its citizenry. Individuals found ways to identify with being Americans. Many flew American flags on their cars, their lawns, and in front of their businesses. Others held vigils for the lives lost in the attacks. Most of us experienced renewed respect and awe for firefighters, police officers, and others in the business of public safety and publicly recognized their efforts. Still others played or watched football, a national pastime, or watched the awkwardness of late-night comedy show hosts who said that they had nothing funny to say. In some communities, many spent time explicitly and publicly defending their American identities. As I began fieldwork in an Iraqi refugee community in Lincoln, Nebraska, in the fall of 2001, I observed young men shaving their beards, and I read daily school bulletins in which teachers and principals encouraged understanding and tolerance, especially of Islam in the United States. Without exhausting the myriad ways people found to display their Americanness, my point is that they did, and in doing so, they had to re-present themselves because they (we) were all participants and observers of our participation as we (they) attempted to answer the "What are you?" question.

Michael Agar (1994) discusses the concept of "languaculture," that one cannot understand a language or culture without being aware of both, of their implicit and explicit connection; in order to understand a "culture," a person has to understand him- or herself in it. For days following the September 11 attack, major television networks engaged us explicitly in a redefining process, one that enacted new cultural and linguistic norms that questioned and analyzed what it means to be American. As Dorinne Kondo writes, "Crafting selves implies a concept of agency: that human beings create, construct, work on, and enact their 
identities, sometimes creatively challenging the limits of cultural constraints which constitute both what we call selves and the ways those selves can be crafted" (1990:48). Of course, in the months and, eventually, years following the attack of September 11, what is at stake is our potential as educators, researchers, and community members to con-. tinue to foster sites, such as schools, classrooms, commiunity centers, homes, and workplaces, where individuals can in fact have the opportunity to craft who they would like to be.

Below, I share two interconnected 'narrative's crafted from my field notes in the months following the attack. These narratives are writing stories, "narratives about contexts in which the writing is produced.... They offer critical reflexivity about the writing-self in different contexts as a valuable creative analytic practice" (Richardson 2000:931). This type of narrative situates the author's writing in the author's life, which for me includes my academic work within my institution and fieldwork in immigrant communities in the months following the September 11 attack. The first narrative, "Being Wanded," is a revised version of an analysis I presented to my university and state community as a,panelist in a discussion about civil liberties versus national security. Across the United States, many of us whose research focuses on immigrant, minority, or low socioeconomic status populations were contacted as "experts" to participate in such panels. In this first narrative,'I draw from field notes of my travels from the Midwest to the East.Coast in November 2001. The second narrative, "Ah Ha' Moments," is based on a recent visit to' my primary site for fieldwork in the 'Yemeni community in southeastern Michigan after a two-year absence (Sarroub 2002b). Both of these narratives evoke questions about the meaning of this catastrophe and serve as reminders that 'our work is contextual, and that the relation- . ship between the social practice of "doing fieldwork" and "writing" is a dialogical one.

\section{Being Wanded}

In November 2001, I flew to New Jersey with a connection in Minneapolis before landing at the Newark airport. While in Minneapolis during my one-hour stay, I encountered a new verb and a new.noun, words in the English language that perfectly illustrate the tragic and sociolinguistic consequences of September 11. People are learning to adapt and are . adopting linguistic forms (and neologisms) to reflect a changing set of. ideas-ways of being in a cultural and socioeconomic market that is telling them to continue to engage in the usual norms of society and at the same time strive to be more alert, 'suspicious, and careful. In effect, they are learning a new social language (Gee 1999), one that reflects the differential politics of the time. People have to position themselves vis-à-vis their own differentiated participation in the social structures they inhabitfor example, airport life-which were affected by September 11. Following the attack, participation in Americanness became categorically 
differentiated according to ethnicity, religion, nationality, and discourse. As the critical discourse analyst Norman Fairclough suggests,

People produce representations of the social world, including representations of themselves and their productive activities-people never simply act, their representations of their actions and domains of action are an inherent part of action, action is reflexive. Different representations tend to be produced from different positions. [2000:164]

Again, at issue is the question "What are you?" and how people choose to or must position themselves during a catastrophe. Before I could surmise that November day that the neologisms I heard were particular to the Minneapolis airport area, I heard them again a few hours later in Newark. In Minneapolis, there was an announcement at my gate: "All passengers. We will proceed to zund you here at the gate. The womder-er will pull individual passengers from the line and ask for your permission to be irmited."

On hearing this, my ears perked up. The only place 1 had ever heard of a wand was in fairytales where magic was orchestrated by a wand usually held by a good fairy, or in the Harry Potter book series, where Harry learns to do magic with his wand. I immediately realized that the gatekeeper to the plane referred to the handheld metal detector that has become a new September 11 reminder in our lives. The wanderer referred to the person who randomly chose people in line for a more extensive search. I heard the same language in Newark where the lines were much longer and where military personnel assisted in the annding of passengers.

To annd is a transitive verb. It is an action verb carried out by one who knows how to wand people who are, in effect, roandees. There is no magic in the act of wanding. The wanderer is not a fairy or magician but a person who has been trained and trusted to look, judge, and wand within a few seconds. These are usually not military personnel but airline workers who are performing an important civil service and who became federal workers when they took on their new wanding identities. Although this phenomenon is relatively new in our public lives, most countries have had such systems of wanding in place for many years, and not just in airports. U.S. citizens are unfortunately not very good at it yet because our perceptions, inexperience, and prejudices often make the wanding less random and more particularly focused. In Minneapolis that November 2001, only young and middle-aged men of darker coloring were wanded. This was especially interesting because the majority of the Minneapolis airport workers-the people who clean and sell food, books, and magazines-are Somali refugees and immigrants whose language is Arabic. What might be their perceptions of the wandings? In Newark, during the two hours that I stood in line to get through the metal detectors, only young and middle-aged men and Muslim women who were completely covered and wore head scarves were wanded. 
Our sensitivity to alternative representations of terrorism has been sparked by the horrors of the 1995 Oklahoma City bombing of the Murrah Building, student shootings among white, middle-class boys in high schools, and before that, the Unabomber and countless other atrocities. Yet we continue to wand in very specific and problematic ways. As one $A E Q$ reviewer of this article aptly pointed out, "Being wanded has different implications depending upon the social location of the wandee. 'Bob from Montana' with a hunting gun is perceived as a lesser threat than 'Mohamed from Newark' with a pair of nail clippers." The neologisms we create are intimately connected to our actions, perceptions, and participation in daily life. Wanding is by no means part of an apolitical discursive language. Chouliaraki and Fairclough underscore the notion that social practices, such as labeling or categorizing, are concretized through the positioning of the individual: "the links between particular discourses and social positions, and therefore the ideological effects of discourse, are established and negotiated in the process of articulation within a practice" (1999:150). For example, recently I had the opportunity to speak with the mail carrier in my neighborhood, who confided that U.S. postal employees worried about delivering mail to "certain" people (Iraqis and Afghans) in nearby neighborhoods, especially in the context of the anthrax mailings. When I asked who these people might be, it became clear that in wanding them by looking at their names, dress, coloring, and speech-albeit without the body check-the mail carrier had concluded that these Midwest residents were potential threats because they were not Euro-American. As the mail carrier articulated the process of wanding, it was clear that that her ideology of Americanness was firmly grounded in a discourse of us versus them, and that I was not wanded in the same way because I did not fit her profile of the typical wandees of whom to be wary.

As I think about our communities in the United States, some of which fly the American flag in a new surge of patriotism, I worry about the fears people have, the words they use, the actions they take. Obviously, we have reason to be fearful and watchful. The crash of the American Airlines flight on November 12, 2001, had many of us at the edge of our seats frantically hoping, ironically and tragically, that it was an accident, an engine failure rather than another attack. Are there ways that as participant observers of catastrophe we can be more critical of our own participation (wanding), especially as we enter into dialogue with others about these issues? This is a key question that alerts us to the fine balance we maintain between protecting ourselves from harm and protecting our civil liberties. We put our trust in the hands of public officials, civil servants, and our colleagues, friends, and families. How fragile that trust becomes with the onslaught of terror, violence, and, sadly, prejudice. Our very words change and as a result, our world changes. This was made all the more evident to me by a Mexican American high school student I recently met during my fieldwork, who said, "I feel safe 
most of the time in school, but people think I'm Arabic instead of Mexican, and my mom doesn't let me go out after school. So, you know, it's hard."

In some ways September 11 has served to further highlight social issues we have faced for decades. In other ways, it has created new ways of being in our homes, communities, nation, and the world. Most of us are adapting. I suggest, as Alan Peshkin (1986) did in his study of Christian fundamentalism and other kinds of fundamentalisms, that we remain vigilant of the emergence of extremist ideologies (there is a distinction here between fundamentalism and extremism in that not all fundamentalists are extremists), and actions that harm civil liberties. In the growing global and digital economy that we inhabit and as people who live in the United States, we must consciously attempt to recognize how individually and collectively through our foreign policies and our media, we create the conditions for extremisms and extremists to flourish. I also believe that we should continue to communicate our fears and hopes very much as we are doing in this issue of $A E Q$. If inventing new words helps us capture who we are in a given moment, then let us invent new words, such as wanding, but let us also make certain that the actions those words embody are exercised with caution, intellect, moderation, and understanding and that we learn from our mistakes, look to our history for guidance, and continue to make steady social progress.

\section{"Ah Ha" Moments}

In their manifesto for the first issue of Ethnograply, editors Paul Willis and Mats Trondman commented that as ethnographers they are interested in producing "ah ha" effects, "where evocative expression through data hits the experience, body and emotions of the reader" (2000:12). The work of the ethnographer is to represent ordinary life in all of its social, political, cultural, and linguistic complexities. In effect, ethnography is both a process and a product (Tedlock 2000), and as such the ethnographer must be attuned to change and be able to recognize it when she or he sees it. Willis and Trondman further explain "ah ha effects" as

moments where new understandings and possibilities are opened up in the space between experience and discourse, at the same time deconstructing and reshaping the taken for granted in a particular response to the shape of the social order, a response which transcends dichotomies such as the public/private, social/individual. "Ah ha" effects fuse old experiences with new ones, thus opening readers' minds toward new horizons. [2000:12]

Such an "ah ha" moment occurred as I began preliminary fieldwork in an Iragi refugee community hundreds of miles from my primary field site in Michigan. On November 25, 2001, CBS aired a 60 Minutes segment, "Arab Americans," which focused on the site in which I had previously conducted two years of field work. This public textual and visual document featured Yemeni American participants from my research. As I watched this representation of the community, my past experiences 
with the people there fused with the new media discourse around terrorism, racial profiling, 'civil liberties, war, discrimination, and 'fear. It was a startling and important moment because some of the women on the CBS show were Muslims who had never wanted their images to be captured on film and made public. Yet, there they were, re-presenting themselves with regard to their Americanness and Islam and becoming part of a very public domain in order to answer the "What 'are you?" question. The attacks of September 11, coupled with intelligence and media investigations, conflated the normative public and private spaces I had observed and about which I have written. My informants' roles in their community were drastically changed as they simultaneously became cultural and religious representatives "of a group under suspicion for terrorism and public apologists of their Americanness or lack of it. As one young woman told me, "We don't know who we are anymore."

The "ah ha" moment was elaborated further' as I listened to an interview in the segment in which an Arab American businessman stated that his community had become' a "big prison with invisible boundaries .. a center of hate crimes" (60 Minutes News Magazine, Novemiber 25, 2001). The media discourse of discrimination was reshaping how this community perceived itself and was perceived by others, and part of the "ah ha," moment, for me as a participant observer, meant critically understanding, based on prior fieldwork experiences, how Arab Americans in this community could find ways to create a social order that valued their "in-betweenness" as 'Americans and immigrants. Prior to September 11, southeastern Michigan was described as a haven for the 300,000 Arabs and Arab Americans residing there,'a place for opportunity and upward socioeconomic mobility. In the television segment, it was clear that the community became the locus for fear, miscommunication, and suspicion: The segment ended with a comment from the Detroit FBI director, who remarked that he believed that Dearborn, Michigan, a metropolitan suburb 'of Detroit, included residents who were concealing their support of terrorism. Whether this is an accurate depiction of the situation remains to be seen, but it has effected a strong resistance among community members, who argue that being American means having the right to be critical of U.S. international policy and feeling safe in expressing that right.

During a visit to the Detroit area in February 2002, I grew more aware of the fragile geopolitical balance maintained by all Americans in the area. This community cannot sustain and live through another terrorist attack in the United States without harm being done to its members. Many of the young women who wear the hijab (head scarf) noted that in the weeks following September 11 they remained at home, away from the public spaces of "non-Arabs" because they were often verbally and physically harassed. Many of the men were questioned and at times taken away by local and federal authorities. The descriptions of their experiences plus those of the 60 Minutes report became all the more 
tangible when one of my Muslim female informants angrily shared a university's student newspaper on-line article published at Wayne State University. At the end of his article, entitled, "Islam Sucks," Joe Fisher attributes the following statement to Pakistani President Pervez Musharraf: "the Muslim world is the poorest, most illiterate, backward, unhealthy, unenlightened, deprived, and weakest of all the races" (2002:2).

By attributing this quote to an insider in the Islamic world, Fisher, an outsider and non-Muslim, validates his own racist claims. The pragmatics of this provide a powerful rhetorical example of racist discourse. His article was copied and shared among Dearborn community members, most of whom were shocked by its contents. I include a few additional excerpts below:

"Some religions suck more than ofhers, though, and one of them is Islam:"

"It's not Muslims that I dislike-l just dislike their faith."

"Fortunately, we have a secular public school system in America that can deprogram the children of Muslim immigrants and help them adopt more productive values."

"Unfortunately, we have countries like Saudi Arabia where children are taught to make friends with Muslims and adopt their traditions." [Fisher 2002]

These excerpts are symbolic of Islamophobia and the kinds of violence incited by the September 11 attacks. Physical and textual violence serve common purposes. They destroy, alienate, reinforce the status quo, and offer little room for reconciliation. The excerpts above illustrate an ideology of negative assimilation of immigrants in our public schools and the eradication of pluralism, openness, and intracultural rapprochement. The we/them nominalizations in Fisher's writing point to the adoption of an ideology that characterizes some of the worst social practices in our society-from slavery to modern hate crimes, to the crimes designated by the United Nations as crimes against humanity. Fisher's newspaper commentary is not a critically constructive "ah ha" moment in our collective histories because experience has already taught us that words are articulations of ideologies and that extremist views cause physical violence. According to Cass Sunstein (1999), a professor of constitutional law, the social practice of treating large groups of people as dehumanized objects (as Fisher does in the excerpts above) incites violence. Writing about people abstractly by labeling them as "What are you?" rather than attempting to understand who we/they are, objectifies us/them as nonhuman beings lacking hopes, fears, and histories. Rhetorical abstraction is a means of violence, just as the stories we write about individuals can help reduce textual and political violence.

\section{Wanding My Way}

Sharing the narratives above, I ffer a critique of our social practices as I understood them after September 11. Fairclough states that "we cannot 
take the role of discourse in social practices for granted, it has to be established through analysis. Any discourse may be more or less important and salient in one practice or set of practices than in another and may change in importance over time" (2000:1). The three discourses (what is war, security versus civil liberties, and inclusion versus discrimination) that grew out of the September 11 tragedy will not become less important over time because they are rooted in larger social practices in which power, authority, oppression, and violence are closely connected and still characterize the world in which we live. Until we learn and teach to find ways to change how we ask questions-from "What are you?" to "Who are you?"-We will continue to struggle with global catastrophes such as the September 11 attack. How we participate in daily life and represent ourselves and others in our work must reflect sound notions of civility and hospitality. The words we use should reflect a critical understanding of our world, a continuous quest for inclusion, and a healthy respect for differences and disagreements. As I conclude this essay on a contemporary social practice that generated the neologism wanding, I . am reminded of Hannah Arendt's (1970:66) wise counsel:

Words can be relied on only if one is sure that their function is to reveal and not to conceal. It is the semblance of rationality, much more than the interests behind it, that provokes rage.

Loukia K. Sarroub is an assistant professor in Teacher's College at the University of Nebraska-Lincoln.

\section{Notes}

Acknowledgments. I am grateful for the thoughtful critiques I received from three anonymous $A E Q$ reviewers. I also thank P. David Pearson for his helpful read of the first draft and Editors Teresa L. McCarty and K. Tsianina Lomawaima for their feedback and support during the revision process.

1. Foucault (1977) uses panopticon as a metaphor for societal surveillance.

2. I thank one of the anonymous reviewers who suggested that I question how flexible the ideology of Americanness is for those who live in marginalized immigrant communities. Although explicating this idea goes beyond the scope of this article, I believe a flexible ideology of Americanness depends on, in some ways, where a community is located geographically. I imagine that marginalized communities in the Detroit, Michigan metropolitan area, where historically, more than 56 language groups coexisted, might be perceived differently from, say, a new immigrant community in Iowa, where there has historically been very little linguistic or ethnic diversity.

\section{References Cited}

60 Minutes News Magazine

2001 Arab Americans. CBS, November 25. 
Agar, Michael

1994 Language Shock: Understanding the Culture of Conversation. New

York: William Morrow.

Arendt, Hannah

1970[1969] On Violence. New York: Harcourt Brace Jovanovich Publishers.

Chouliaraki, Lillie, and Norman Fairclough

1999 Discourse in Late Modernity: Rethinking Critical Discourse Analysis.

Edinburgh: Edinburgh University Press.

Gee, James P.

1999 Discourse Analysis: Theory and Method. London: Routledge.

Fairclough, Norman

2000 Discourse, Social Theory and Social Research. Journal of Sociolinguistics 4(2):163-195.

Fisher, Joe

2002 Islam Sucks. The South End: The Official Student Newspaper of Wayne

State University. Electronic document, http://www.southend.wayne.edu/

days/feb2002/2262002/oped/islam/islam.html, accessed August 23.

Foucault, Michel

1977 Discipline and Punish. New York: Vintage.

Kondo, Dorrine K.

1990 Crafting Selves: Power, Gender, and Discourses of Identity in a Japanese Workplace. Chicago: University of Chicago Press.

Peshkin, Alan

1986 God's Choice: The Total World of a Fundamentalist Christian School.

Chicago: University of Chicago Press.

Richardson, Laurel

2000 Writing: A Method of Inquiry. In The Handbook of Qualitative Research. Norman Denzin and Yvonna Lincoln, eds. Pp. 923-948. Thousand

Oaks, CA: Sage Publications.

Rodriguez, Gregory

2001 Identify Yourself: Who's American? New York Times, September 23: D1.

Sarroub, Loukia K.

2001 The Sojourner Experience of Yemeni American High School Students: An Ethnographic Portrait. Harvard Educational Review 7(3):390-415.

2002a Arab American Youth in Perspective. Society for Research on Adolescence Newsletter (spring):3, 6 .

$2002 b$ "In-betweeness": Religion and Conflicting Visions of Literacy. Reading Research Quarterly 37(2):130-148.

Sunstein, Cass R.

1999 Is Violent Speech a Right? In An Interdisciplinary Reader: Violence and

Its Alternatives. Manfred B. Steger and Nancy S. Lind, eds. Pp. 89-92. New

York: St. Martin's Press.

Tedlock, Barbara

2000 Ethnography and Ethnographic Representation. In The Handbook of

Qualitative Research. Norman Denzin and Yvonna Lincoln, eds. Pp. 455-486. Thousand Oaks, CA: Sage Publications.

Willis, Paul, and Mats Trondman

2000 Manifesto for Ethnography. Ethnography 1(1):5-16. 


\section{From Neologisms to Social Practice: An Analysis of the Wanding of America}

\author{
Loukia K. Sarroub
}

Anthropology \& Education Quarterly 33:3 (Spring 2002), pp. 297-307.

\begin{abstract}
In this article I discuss how individuals and communities in the United States re-present themselves in the context of the September 11 tragedy and its complex aftermath. My aim is to explore the "American" discourse on inclusion and discrimination by examining the neologisms and social practices that were amplified by the attack in local and national debates.
\end{abstract}

\section{CRAFTING POST-SEPTEMBER 11 SELVES}

As an immigrant of North African (Algerian) and European (Greek) descent, and as an American living in the Midwest, I, like many others, participated in public and media discourses focused on ethnicity and religion in the aftermath of the September 11 attacks. Throughout the fall of 2001, I noticed as a participant in these debates that among people who use hyphenated labels, I was perceived and categorized as either Euro-American or Arab American, and among some, I was regarded as a hybrid (an American), while among others who questioned my "unusual" name, the inevitable question arose, "So, what are you?" I wondered if there is a way to respond to the dilemma that the "What are you?" question poses in times of crisis and catastrophe. In the wake of the attack, I became more interested in understanding how our communities adapt to the often subtle and sometimes explicit demands on our emotions, time, and intellect in the private and public spaces of our lives such as schools, communities, and homes. How do individuals and communities re-present themselves in the context of such an attack and its complex and complicated aftermath?
It has long been considered a truism that how we perceive, represent, and act around others defines our individual and collective identities. The September 11 tragedy and the ensuing political and military events rendered people in the United States and elsewhere more sensitive to the particularities of perception and representation. In my own scholarship, I have suggested that immigrant communities live in the "in-between" spaces created in the nexus of ethnicity, nationality, and culture, and that people's textual and social practices reflect and refract their in-betweenness (Sarroub 2002b). However, during times of crisis, people inevitably have to choose how to represent themselves in order to survive, and being "in-between" may not satisfy common local and national expectations of what it means to be a member of a given community.

My own "Algerianness" was foregrounded both on personal and professional levels after September 11. For example, like most people around the world, I watched and read the news avidly; I cringed every time I noted that yet another individual from the Middle East was part of the attack, and I was ever watchful of Algerians' possible participation in this act of terror. I watched and I, too, wondered if I was watched under the panoptican-like gaze. The "What are you?" question became a haunting metaphor for the fear and apprehension I witnessed in various immigrant communities, and my work on Arab Muslim youth in the United States became more significant as I attempted to answer hundreds of questions from educators, researchers, and my neighbors (Sarroub 2001, 2002a). People wanted to know more, for example, about where these Arab and Arab American communities are located, who the youth are in our schools, and how they might be related to the events of September 11.

This process of answering questions and looking at research through the tragic lens of September 11 indexed something new in my work and that of colleagues who study a range of communities in the United States. Catastrophic events and their consequences had to be interrogated through a critical lens no matter where they occurred. Research sites were no longer just schools or communities that could be discretely described, analyzed, and then discussed in the research community. The geopolitical ramifications of the attack underscored the notion that everyone is an active participant, a participant observer, and deeply implicated in the consequences of such a catastro- 
phe, especially in this digital age when images and text are so quickly and easily accessible. In effect, we all became observers of our participation as individuals across the United States and elsewhere grew more watchful, or as the case may be, more watched.

Since September 11, people in the United States and much of the world have been engaged in three broad discourses regarding war, security versus civil liberties, and inclusion and discrimination. For example, we have all wondered if we are at war and if fighting terrorist networks means that we are fighting a new kind of war. Most of us have experienced the new security measures at airports and debated the advantages and disadvantages of national identification cards. Finally, in the United States, discrimination and "racial profiling" at all social and professional levels have long and complicated histories and continue to be problematic societal issues.

My aim here is to further explore the third discourse on inclusion and discrimination in the context of my research in Arab American communities. At the heart of this discussion are the questions: "Who is American?" and, "What does it mean to be an American?" Both closely relate to the "What are you?" question. Since September 11, we have observed, watched, and participated in a public accounting of this question. For example, in the September 23, 2001, New York Times article, "Identify Yourself: Who's American?" Gregory Rodriguez makes the following observations about U.S. society:

1. Not until the 1960s was it permissible for immigrants to adhere to their cultural heritages. The definition of citizenship shifted from belief in a common culture to following shared ideals.

2 . Since the 1970 s, multiculturalism nurtured unprecedented levels of public tolerance of ethnic and racial differences and respect for hyphenated identities.

3 . Some people even espoused a form of multiculturalism that challenged the need for immigrants and other minorities to identify with America at all.

4. By the end of the 20th century, being American simply meant being a participant in the search for wealth and stability. [Rodriguez 2001: D1]
The attack of September 11 changed what seems to have been a rather flexible ideology of Americanness. The attack provoked renewed vigor and an explicit accounting of its citizenry. Individuals found ways to identify with being Americans. Many flew American flags on their cars, their lawns, and in front of their businesses. Others held vigils for the lives lost in the attacks. Most of us experienced renewed respect and awe for firefighters, police officers, and others in the business of public safety and publicly recognized their efforts. Still others played or watched football, a national pastime, or watched the awkwardness of late-night comedy show hosts who said that they had nothing funny to say. In some communities, many spent time explicitly and publicly defending their American identities. As I began fieldwork in an Iraqi refugee community in Lincoln, Nebraska, in the fall of 2001, I observed young men shaving their beards, and I read daily school bulletins in which teachers and principals encouraged understanding and tolerance, especially of Islam in the United States. Without exhausting the myriad ways people found to display their Americanness, my point is that they did, and in doing so, they had to re-present themselves because they (we) were all participants and observers of our participation as we (they) attempted to answer the "What are you?" question.

Michael Agar (1994) discusses the concept of "languaculture," that one cannot understand a language or culture without being aware of both, of their implicit and explicit connection; in order to understand a "culture," a person has to understand him- or herself in it. For days following the September 11 attack, major television networks engaged us explicitly in a redefining process, one that enacted new cultural and linguistic norms that questioned and analyzed what it means to be American. As Dorinne Kondo writes, "Crafting selves implies a concept of agency: that human beings create, construct, work on, and enact their identities, sometimes creatively challenging the limits of cultural constraints which constitute both what we call selves and the ways those selves can be crafted" (1990:48). Of course, in the months and, eventually, years following the attack of September 11, what is at stake is our potential as educators, researchers, and community members to continue to foster sites, such as schools, classrooms, community centers, homes, and workplaces, where individuals can in fact have the opportunity to craft who they would like to be. 
Below, I share two interconnected narratives crafted from my field notes in the months following the attack. These narratives are writing stories, "narratives about contexts in which the writing is produced.... They offer critical reflexivity about the writing-self in different contexts as a valuable creative analytic practice" (Richardson 2000:931). This type of narrative situates the author's writing in the author's life, which for me includes my academic work within my institution and fieldwork in immigrant communities in the months following the September 11 attack. The first narrative, "Being Wanded," is a revised version of an analysis I presented to my university and state community as a panelist in a discussion about civil liberties versus national security. Across the United States, many of us whose research focuses on immigrant, minority, or low socioeconomic status populations were contacted as "experts" to participate in such panels. In this first narrative, I draw from field notes of my travels from the Midwest to the East Coast in November 2001. The second narrative, "Ah $\mathrm{Ha}$ Moments," is based on a recent visit to my primary site for fieldwork in the Yemeni community in southeastern Michigan after a two-year absence (Sarroub 2002b). Both of these narratives evoke questions about the meaning of this catastrophe and serve as reminders that our work is contextual, and that the relationship between the social practice of "doing fieldwork" and "writing" is a dialogical one.

\section{BEING WANDED}

In November 2001, I flew to New Jersey with a connection in Minneapolis before landing at the Newark airport. While in Minneapolis during my one-hour stay, I encountered a new verb and a new noun, words in the English language that perfectly illustrate the tragic and sociolinguistic consequences of September 11. People are learning to adapt and are adopting linguistic forms (and neologisms) to reflect a changing set of ideas--ways of being in a cultural and socioeconomic market that is telling them to continue to engage in the usual norms of society and at the same time strive to be more alert, suspicious, and careful. In effect, they are learning a new social language (Gee 1999), one that reflects the differential politics of the time. People have to position themselves vis-à-vis their own differentiated participation in the social structures they inhabit--for example, airport life--which were affected by September 11. Following the attack, participation in Americanness became categorically differentiated according to ethnicity, religion, nationality, and discourse. As the critical discourse analyst Norman Fairclough suggests,

People produce representations of the social world, including representations of themselves and their productive activities--people never simply act, their representations of their actions and domains of action are an inherent part of action, action is reflexive. Different representations tend to be produced from different positions. [2000:164]

Again, at issue is the question "What are you?" and how people choose to or must position themselves during a catastrophe. Before I could surmise that November day that the neologisms I heard were particular to the Minneapolis airport area, I heard them again a few hours later in Newark. In Minneapolis, there was an announcement at my gate: "All passengers. We will proceed to wand you here at the gate. The wander-er will pull individual passengers from the line and ask for your permission to be wanded."

On hearing this, my ears perked up. The only place I had ever heard of a wand was in fairytales where magic was orchestrated by a wand usually held by a good fairy, or in the Harry Potter book series, where Harry learns to do magic with his wand. I immediately realized that the gatekeeper to the plane referred to the handheld metal detector that has become a new September 11 reminder in our lives. The wanderer referred to the person who randomly chose people in line for a more extensive search. I heard the same language in Newark where the lines were much longer and where military personnel assisted in the wanding of passengers.

To wand is a transitive verb. It is an action verb carried out by one who knows how to wand people who are, in effect, wandees. There is no magic in the act of wanding. The wanderer is not a fairy or magician but a person who has been trained and trusted to look, judge, and wand within a few seconds. These are usually not military personnel but airline workers who are performing an important civil service and who became federal workers when they took on their new wanding identities. Although this phenomenon is relatively new in our public lives, most countries have had such systems of wanding in place for many years, and not just in airports. U.S. citizens are unfortunately not very good at it yet because our perceptions, inexperience, and 
prejudices often make the wanding less random and more particularly focused. In Minneapolis that November 2001, only young and middle-aged men of darker coloring were wanded. This was especially interesting because the majority of the Minneapolis airport workers-the people who clean and sell food, books, and magazines--are Somali refugees and immigrants whose language is Arabic. What might be their perceptions of the wandings? In Newark, during the two hours that I stood in line to get through the metal detectors, only young and middle-aged men and Muslim women who were completely covered and wore head scarves were wanded.

Our sensitivity to alternative representations of terrorism has been sparked by the horrors of the 1995 Oklahoma City bombing of the Murrah Building, student shootings among white, middle-class boys in high schools, and before that, the Unabomber and countless other atrocities. Yet we continue to wand in very specific and problematic ways. As one AEQ reviewer of this article aptly pointed out, "Being wanded has different implications depending upon the social location of the wandee. 'Bob from Montana' with a hunting gun is perceived as a lesser threat than 'Mohamed from Newark' with a pair of nail clippers." The neologisms we create are intimately connected to our actions, perceptions, and participation in daily life. Wanding is by no means part of an apolitical discursive language. Chouliaraki and Fairclough underscore the notion that social practices, such as labeling or categorizing, are concretized through the positioning of the individual: "the links between particular discourses and social positions, and therefore the ideological effects of discourse, are established and negotiated in the process of articulation within a practice" (1999:150). For example, recently I had the opportunity to speak with the mail carrier in my neighborhood, who confided that U.S. postal employees worried about delivering mail to "certain" people (Iraqis and Afghans) in nearby neighborhoods, especially in the context of the anthrax mailings. When I asked who these people might be, it became clear that in wanding them by looking at their names, dress, coloring, and speech--albeit without the body check--the mail carrier had concluded that these Midwest residents were potential threats because they were not Euro-American. As the mail carrier articulated the process of wanding, it was clear that that her ideology of Americanness was firmly grounded in a discourse of us versus them, and that I was not wanded in the same way because I did not fit her profile of the typical wandees of whom to be wary.

As I think about our communities in the United States, some of which fly the American flag in a new surge of patriotism, I worry about the fears people have, the words they use, the actions they take. Obviously, we have reason to be fearful and watchful. The crash of the American Airlines flight on November 12, 2001, had many of us at the edge of our seats frantically hoping, ironically and tragically, that it was an accident, an engine failure rather than another attack. Are there ways that as participant observers of catastrophe we can be more critical of our own participation (wanding), especially as we enter into dialogue with others about these issues? This is a key question that alerts us to the fine balance we maintain between protecting ourselves from harm and protecting our civil liberties. We put our trust in the hands of public officials, civil servants, and our colleagues, friends, and families. How fragile that trust becomes with the onslaught of terror, violence, and, sadly, prejudice. Our very words change and as a result, our world changes. This was made all the more evident to me by a Mexican American high school student I recently met during my fieldwork, who said, "I feel safe most of the time in school, but people think I'm Arabic instead of Mexican, and my mom doesn't let me go out after school. So, you know, it's hard."

In some ways September 11 has served to further highlight social issues we have faced for decades. In other ways, it has created new ways of being in our homes, communities, nation, and the world. Most of us are adapting. I suggest, as Alan Peshkin (1986) did in his study of Christian fundamentalism and other kinds of fundamentalisms, that we remain vigilant of the emergence of extremist ideologies (there is a distinction here between fundamentalism and extremism in that not all fundamentalists are extremists), and actions that harm civil liberties. In the growing global and digital economy that we inhabit and as people who live in the United States, we must consciously attempt to recognize how individually and collectively through our foreign policies and our media, we create the conditions for extremisms and extremists to flourish. I also believe that we should continue to communicate our fears and hopes very much as we are doing in this issue of AEQ. If inventing new words helps us capture who we are in a given moment, then let us invent new words, such as wanding, but 
let us also make certain that the actions those words embody are exercised with caution, intellect, moderation, and understanding and that we learn from our mistakes, look to our history for guidance, and continue to make steady social progress.

\section{"AH HA" MOMENTS}

In their manifesto for the first issue of Ethnography, editors Paul Willis and Mats Trondman commented that as ethnographers they are interested in producing "ah ha" effects, "where evocative expression through data hits the experience, body and emotions of the reader" (2000:12). The work of the ethnographer is to represent ordinary life in all of its social, political, cultural, and linguistic complexities. In effect, ethnography is both a process and a product (Tedlock 2000), and as such the ethnographer must be attuned to change and be able to recognize it when she or he sees it. Willis and Trondman further explain "ah ha effects" as

moments where new understandings and possibilities are opened up in the space between experience and discourse, at the same time deconstructing and reshaping the taken for granted in a particular response to the shape of the social order, a response which transcends dichotomies such as the public/private, social/individual. "Ah ha" effects fuse old experiences with new ones, thus opening readers' minds toward new horizons. [2000:12]

Such an "ah ha" moment occurred as I began preliminary fieldwork in an Iraqi refugee community hundreds of miles from my primary field site in Michigan. On November 25, 2001, CBS aired a 60 Minutes segment, "Arab Americans," which focused on the site in which I had previously conducted two years of fieldwork. This public textual and visual document featured Yemeni American participants from my research. As I watched this representation of the community, my past experiences with the people there fused with the new media discourse around terrorism, racial profiling, civil liberties, war, discrimination, and fear. It was a startling and important moment because some of the women on the CBS show were Muslims who had never wanted their images to be captured on film and made public. Yet, there they were, re-presenting themselves with regard to their Americanness and Islam and becoming part of a very public domain in order to answer the
"What are you?" question. The attacks of September 11, coupled with intelligence and media investigations, conflated the normative public and private spaces I had observed and about which I have written. My informants' roles in their community were drastically changed as they simultaneously became cultural and religious representatives of a group under suspicion for terrorism and public apologists of their Americanness or lack of it. As one young woman told me, "We don't know who we are anymore."

The "ah ha" moment was elaborated further as I listened to an interview in the segment in which an Arab American businessman stated that his community had become a "big prison with invisible boundaries ... a center of hate crimes" (60 Minutes News Magazine, November 25, 2001). The media discourse of discrimination was reshaping how this community perceived itself and was perceived by others, and part of the "ah ha," moment, for me as a participant observer, meant critically understanding, based on prior fieldwork experiences, how Arab Americans in this community could find ways to create a social order that valued their "in-betweenness" as Americans and immigrants. Prior to September 11, southeastern Michigan was described as a haven for the 300,000 Arabs and Arab Americans residing there, a place for opportunity and upward socioeconomic mobility. In the television segment, it was clear that the community became the locus for fear, miscommunication, and suspicion. The segment ended with a comment from the Detroit FBI director, who remarked that he believed that Dearborn, Michigan, a metropolitan suburb of Detroit, included residents who were concealing their support of terrorism. Whether this is an accurate depiction of the situation remains to be seen, but it has effected a strong resistance among community members, who argue that being American means having the right to be critical of U.S. international policy and feeling safe in expressing that right.

During a visit to the Detroit area in February 2002, I grew more aware of the fragile geopolitical balance maintained by all Americans in the area. This community cannot sustain and live through another terrorist attack in the United States without harm being done to its members. Many of the young women who wear the hijab (head scarf) noted that in the weeks following September 11 they remained at home, away from the public spaces of "non-Arabs" because they were 
often verbally and physically harassed. Many of the men were questioned and at times taken away by local and federal authorities. The descriptions of their experiences plus those of the 60 Minutes report became all the more tangible when one of my Muslim female informants angrily shared a university's student newspaper on-line article published at Wayne State University. At the end of his article, entitled, "Islam Sucks," Joe Fisher attributes the following statement to Pakistani President Pervez Musharraf: "the Muslim world is the poorest, most illiterate, backward, unhealthy, unenlightened, deprived, and weakest of all the races" (2002:2).

By attributing this quote to an insider in the Islamic world, Fisher, an outsider and non-Muslim, validates his own racist claims. The pragmatics of this provide a powerful rhetorical example of racist discourse. His article was copied and shared among Dearborn community members, most of whom were shocked by its contents. I include a few additional excerpts below:

"Some religions suck more than others, though, and one of them is Islam:"

"It's not Muslims that I dislike--I just dislike their faith."

"Fortunately, we have a secular public school system in

America that can deprogram the children of Muslim immi-

grants and help them adopt more productive values."

"Unfortunately, we have countries like Saudi Arabia where children are taught to make friends with Muslims and adopt their traditions." [Fisher 2002]

These excerpts are symbolic of Islamophobia and the kinds of violence incited by the September 11 attacks. Physical and textual violence serve common purposes. They destroy, alienate, reinforce the status quo, and offer little room for reconciliation. The excerpts above illustrate an ideology of negative assimilation of immigrants in our public schools and the eradication of pluralism, openness, and intracultural rapprochement. The we/them nominalizations in Fisher's writing point to the adoption of an ideology that characterizes some of the worst social practices in our society--from slavery to modern hate crimes, to the crimes designated by the United Nations as crimes against humanity. Fisher's newspaper commentary is not a critically constructive "ah ha" moment in our collective histories because ex- perience has already taught us that words are articulations of ideologies and that extremist views cause physical violence. According to Cass Sunstein (1999), a professor of constitutional law, the social practice of treating large groups of people as dehumanized objects (as Fisher does in the excerpts above) incites violence. Writing about people abstractly by labeling them as "What are you?" rather than attempting to understand who we/they are, objectifies us/them as nonhuman beings lacking hopes, fears, and histories. Rhetorical abstraction is a means of violence, just as the stories we write about individuals can help reduce textual and political violence.

\section{WANDING MY WAY}

Sharing the narratives above, I offer a critique of our social practices as I understood them after September 11. Fairclough states that "we cannot take the role of discourse in social practices for granted, it has to be established through analysis. Any discourse may be more or less important and salient in one practice or set of practices than in another and may change in importance over time" (2000:1). The three discourses (what is war, security versus civil liberties, and inclusion versus discrimination) that grew out of the September 11 tragedy will not become less important over time because they are rooted in larger social practices in which power, authority, oppression, and violence are closely connected and still characterize the world in which we live. Until we learn and teach to find ways to change how we ask questions--from "What are you?" to "Who are you?"--we will continue to struggle with global catastrophes such as the September 11 attack. How we participate in daily life and represent ourselves and others in our work must reflect sound notions of civility and hospitality. The words we use should reflect a critical understanding of our world, a continuous quest for inclusion, and a healthy respect for differences and disagreements. As I conclude this essay on a contemporary social practice that generated the neologism wanding, I am reminded of Hannah Arendt's (1970:66) wise counsel:

Words can be relied on only if one is sure that their function is to reveal and not to conceal. It is the semblance of rationality, much more than the interests behind it, that provokes rage. 
Loukia K. Sarroub is an assistant professor in Teacher's College at the University of Nebraska-Lincoln.

Acknowledgments. I am grateful for the thoughtful critiques I received from three anonymous AEQ reviewers. I also thank P. David Pearson for his helpful read of the first draft and Editors Teresa L. McCarty and K. Tsianina Lomawaima for their feedback and support during the revision process.

\section{FOOTNOTES}

1. Foucault (1977) uses panopticon as a metaphor for societal surveillance.

2. I thank one of the anonymous reviewers who suggested that I question how flexible the ideology of Americanness is for those who live in marginalized immigrant communities. Although explicating this idea goes beyond the scope of this article, I believe a flexible ideology of Americanness depends on, in some ways, where a community is located geographically. I imagine that marginalized communities in the Detroit, Michigan metropolitan area, where historically, more than 56 language groups coexisted, might be perceived differently from, say, a new immigrant community in Iowa, where there has historically been very little linguistic or ethnic diversity.

\section{REFERENCES CITED}

60 Minutes News Magazine 2001 Arab Americans. CBS, November 25.

Agar, Michael 1994 Language Shock: Understanding the Culture of Conversation. New York: William Morrow.

Arendt, Hannah 1970[1969] On Violence. New York: Harcourt Brace Jovanovich Publishers.

Chouliaraki, Lillie, and Norman Fairclough 1999 Discourse in Late Modernity: Rethinking Critical Discourse Analysis. Edinburgh: Edinburgh University Press.

Gee, James P. 1999 Discourse Analysis: Theory and Method. London: Routledge.
Fairclough, Norman 2000 Discourse, Social Theory and Social Research. Journal of Sociolinguistics 4(2):163-195.

Fisher, Joe 2002 Islam Sucks. The South End: The Official Student Newspaper of Wayne State University. Electronic document, http://www.southend.wayne.edu/days/feb2002/2262002/oped/islam/isla m.html, accessed August 23.

Foucault, Michel 1977 Discipline and Punish. New York: Vintage.

Kondo, Dorrine K. 1990 Crafting Selves: Power, Gender, and Discourses of Identity in a Japanese Workplace. Chicago: University of Chicago Press.

Peshkin, Alan 1986 God's Choice: The Total World of a Fundamentalist Christian School. Chicago: University of Chicago Press.

Richardson, Laurel 2000 Writing: A Method of Inquiry. In The Handbook of Qualitative Research. Norman Denzin and Yvonna Lincoln, eds. Pp. 923-948. Thousand Oaks, CA: Sage Publications.

Rodriguez, Gregory 2001 Identify Yourself: Who's American? New York Times, September 23: D1.

Sarroub, Loukia K. 2001 The Sojourner Experience of Yemeni American High School Students: An Ethnographic Portrait. Harvard Educational Review 7(3):390-415.

2002a Arab American Youth in Perspective. Society for Research on Adolescence Newsletter (spring):3, 6 .

2002b "In-betweeness": Religion and Conflicting Visions of Literacy. Reading Research Quarterly 37(2):130-148.

Sunstein, Cass R. 1999 Is Violent Speech a Right? In An Interdisciplinary Reader: Violence and Its Alternatives. Manfred B. Steger and Nancy S. Lind, eds. Pp. 89-92. New York: St. Martin's Press.

Tedlock, Barbara 2000 Ethnography and Ethnographic Representation. In The Handbook of Qualitative Research. Norman Denzin and Yvonna Lincoln, eds. Pp. 455-486. Thousand Oaks, CA: Sage Publications.

Willis, Paul, and Mats Trondman 2000 Manifesto for Ethnography. Ethnography 1(1):5-16. 